\author{
PRZEMYSŁAW KACZMAREK \\ ORCID: 0000-0002-3436-4043 \\ Uniwersytet Wrocławski \\ Katedra Teorii i Filozofii Prawa
}

\title{
ROLA PRAWNIKA JAKO ARGUMENT W OBRONIE ETYKI KODEKSOWEJ
}

\begin{abstract}
Abstrakt: Celem niniejszego artykułu jest przedstawienie argumentacji na rzecz pojmowania kodeksu etycznego jako instytucjonalnej ramy reguł, w ramach których prawnik powinien się poruszać, oraz celów, do których ma dążyć. Przedstawione zadanie zamierzam zrealizować w trzech punktach. Najpierw zaprezentuję główne zarzuty stawiane etyce kodeksowej. W argumentacji tej podnosi się, że kodeksowy charakter etyki zawodowej prowadzi albo może prowadzić do marginalizacji moralnej odpowiedzialności oraz utraty sprawstwa podmiotowego. Następnie przejdę do obrony etyki kodeksowej. W tym celu odwołam się do tytułowego pojęcia roli, wykazując, że sytuacja konfliktu w zawodzie prawnika jest cechą tej profesji, dlatego konieczne jest budowanie instytucjonalnej ramy, która pozwala na skoordynowaną działalność w obliczu rozmaitych napięć. Argument ten wzmacnia przedstawianie kodeksu etycznego jako zabezpieczenia przed wyjściem prawnika z roli w sytuacji konfliktu związanego z działalnością zawodową. Celem tego zabezpieczenia jest ochrona klienta.
\end{abstract}

Słowa kluczowe: prawnik, rola zawodowa, etyka kodeksowa, moralna odpowiedzialność

\section{WPROWADZENIE}

W filmie Filadelfia w reżyserii Jonathana Demme'a jest scena przedstawiająca rozmowę dwóch prawników. Jednym z nich jest Andrew Beckett, w którego rolę wciela się Tom Hanks, a drugim Joe Miller, grany przez Denzela Washingtona. Andrew Beckett pozywa swoich pracodawców o to, że został zwolniony z pracy nie $\mathrm{w}$ wyniku niekompetencji zawodowej, ale z powodu choroby. Jest bowiem nosicielem wirusa HIV. Pełnomocnikiem A. Becketta zostaje J. Miller, który w trakcie rozprawy pyta go:

- Za co kochasz prawo?

- Za wiele rzeczy.

- Ale za co najbardziej?

- Co jakiś czas, nie często, ale od czasu do czasu, dzięki mnie sprawiedliwości staje się zadość. Przechodzi wtedy przeze mnie dreszczyk emocji.

— Dziękuję, Andrew. 
Przywołana scena ilustruje sprawczy moment działania w praktyce zawodowej. Nie ukrywam, że wskazana sprawczość podmiotowa jest atrakcyjna i pozwala budować etos zawodu. Ponadto sprawczość ta kształtuje poczucie odpowiedzialności za podejmowane decyzje, a także jest ważnym składnikiem umiejętności dostrzeżenia i nazwania niewłaściwych praktyk. Niemniej nadmierna ekspozycja sprawstwa za cenę niedoceniania infrastruktury prawnej może okazać się kosztowna. Wykonywanie zawodu prawnika oparte jest na zaufaniu, że to rozpoznawalne intersubiektywne czynniki, takie jak tekst prawny, kultura zawodowa, są ważnymi determinantami mającymi wpływ na podejmowane decyzje. Jedną $\mathrm{z}$ formalnych kotwic pomagających zachowywać standardy zawodowe $\mathrm{w}$ trakcie dokonywanych czynności są kodeksy etyczne, regulujące zasady i reguły wykonywanej profesji. W wizji tej są one ramą wyznaczającą działanie prawnika. $\mathrm{Na}$ rzecz proponowanego ujęcia można przywołać argument stabilizacyjny, przedstawiający funkcję etyki zawodowej jako mechanizmu układania relacji między ludźmi ${ }^{1}$. Postanowienia zawodowe poprzez kształtowanie tych relacji mogą sprzyjać zachowaniu dystansu zawodowego i w konsekwencji chronić prawnika przed zbyt emocjonalnym zaangażowaniem się w sprawę². Wzmacniając ten argument, można wskazać na konkluzywny charakter dyskursu prawniczego jako odpowiedź na przeciąganie ponad miarę debaty o dylematach moralnych.

W prezentowanym artykule chciałbym przedstawić argumentację na rzecz pojmowania kodeksu etycznego jako instytucjonalnej ramy umożliwiającej skoordynowane działanie, zwłaszcza w zakresie rozstrzygania dylematów moralnych. W tym celu zamierzam wykazać, że zawód prawnika jest rolą konfliktową i dlatego w kodeksie etycznym można upatrywać (dodatkowego) zabezpieczenia przed wyjściem jurysty z roli w sytuacji konfliktu czy też napięcia związanego z działalnością zawodową ${ }^{3}$. Celem tego zabezpieczenia jest ochrona klienta.

Wskazane zadanie zamierzam zrealizować w trzech punktach. Najpierw zaprezentuję główne zarzuty stawiane etyce kodeksowej (pkt 1). W kolejnym kroku przejdę do jej obrony. W tym celu wykażę, że sytuacja konfliktu w roli zawodowej jest cechą tej profesji, dlatego konieczne jest budowanie instytucjonalnej ramy, która pozwala na skoordynowaną działalność w obliczu rozmaitych napięć (pkt 2). Argument ten wzmacnia przedstawianie zawodu prawnika jako społecznej obietnicy do wywiązywania się z przewidzianego zadania w postaci ochrony klienta, którym może być każdy z nas (pkt 3).

${ }^{1}$ Zob. M. Michalik, Spoleczne przestanki, swoistość i funkcje etyki zawodowej, [w:] Etyka zawodowa, red. A. Sarapata, Warszawa 1971, s. 25 n.

${ }^{2}$ Zob. P. Łuków, Moralność medycyny. O sztuce dobrego życia i o sztuce leczenia, Warszawa 2012, s. 19; J. Naumann, Zbiór Zasad Etyki Adwokackiej i Godności Zawodu. Komentarz, Warszawa 2017, s. 163.

${ }^{3}$ Pisząc o roli prawnika, mam na uwadze przede wszystkim zawód profesjonalnego pełnomocnika procesowego, to jest adwokata i radcy prawnego. Ponadto pojęciem prawnik-jurysta posługuję się zamiennie. Zob. S. Taekema, How to be a transnational jurist: Reflections on Cotterrell's sociological jurisprudence, „Ratio Juris” 32, 2019, nr 4, s. 510-512. 


\section{ETYKA KODEKSOWA JAKO ZORGANIZOWANA NIEODPOWIEDZIALNOŚĆ?4}

W cenionym eseju Etyka bez kodeksu Leszek Kołakowski przedstawia następujący obraz etyki kodeksowej:

kodeks mówi nam, które nakazy są bezwarunkowe, a które ograniczone okolicznościami, mówi także o tym, jakie wartości należy przedkładać nad inne; żaden kodeks nie jest naprawdę ostatecznie wyczerpujący, jednakże idea kodeksu zawiera w sobie dążność stałą do uzyskania ideału kompletności, a więc do takiego zbioru reguł, które dają się zastosować do dowolnej sytuacji moralnej i zawsze ją przesądzać jednoznacznie. Ideał kodeksu to ideał doskonale rozstrzygalnego systemu, z którego, w połączeniu z opisem sytuacji, da się wydedukować dowolny sąd wartościujący5.

Moim zdaniem wiele głosów krytycznych formułowanych wobec kodyfikacji etyki zawodowej dotyczy zaprezentowanej wizji kodeksu6. Krytyka ta opiera się na dwóch podstawowych zarzutach. Dla pierwszego z nich kluczowe jest pytanie, czym jest kodeks etyczny, z kolei w obrębie drugiego zarzutu podnosi się (będące konsekwencją odpowiedzi na to pytanie) racje aksjologiczne.

Pierwszy z zarzutów opiera się na założeniu, że kodeks etyczny jest zbiorem reguł, w którym pojawiające się dylematy moralne są już rozstrzygnięte i do których rozwiązań można się odwołać z poczuciem, że postępuje się właściwie. W tej perspektywie człowiek staje się jedynie odbiorcą imperatywów instytucjonalnych, których dostarcza kodeks. W ujęciu tym kodeks etyczny zakłada istnienie twardego punktu oparcia, do którego dostosowanie się oferuje pewność działania, rozstrzygania pojawiających się dylematów. W tym celu tożsamość podmiotu kształtowana jest na podstawie czynnika zewnętrznego, co ma pozwolić na odciążenie od rozstrzygania pojawiających się dylematów bądź spowodować, że nie zostaną one przez niego zauważone. Takie rozstrzygnięcie jest przejawem tęsknoty za pewnością działania $\mathrm{w}$ instytucji, która ma zapewniać twardy punkt oparcia. Dostosowanie się do niego, postępowanie w zgodzie z nim ma być gwarantem „właściwego" działania. Taką wizję kodeksu charakteryzuje wiara w możliwość uprawomocnienia jednego wzorca działania, który, niczym algorytm, odciąży podmiot od rozstrzygania dylematów moralnych czy też poznawczych.

${ }^{4} \mathrm{~W}$ tym punkcie korzystam $\mathrm{z}$ ustaleń, które przedstawiłem w tekście Kodeksy etyki zawodowej: w poszukiwaniu bezpieczeństwa moralnego w czasach niepewności, [w:] Etyka prawnicza. Stanowiska i perspektywy 3, red. H. Izdebski, P. Skuczyński, Warszawa 2013, s. 19 n.

${ }^{5}$ L. Kołakowski, Etyka bez kodeksu, [w:] idem, Kultura i fetysze. Eseje, Warszawa 2009, s. 153.

${ }^{6}$ Zob. I. Bogucka, T. Pietrzykowski, Etyka w administracji publicznej, Warszawa 2009, s. 118-119; M. Zirk-Sadowski, Postulat etyki bezkodeksowej a stosunek prawa do moralności, „Zeszyty Naukowe Uniwersytetu Łódzkiego. Nauki Humanistyczno-Społeczne”, seria I, 1979, z. 25, s. 3 n.; M. Pieniążek, Etyka sytuacyjna prawnika, Warszawa 2008, rozdz. III; P. Skuczyński, Etyka adwokatów i radców prawnych, Warszawa 2016, s. 77-87. 
Druga oś krytyki wobec etyki kodeksowej dotyczy konsekwencji aksjologicznych. W argumentacji tej podnosi się, że kodeksowy charakter etyki zawodowej prowadzi (teza mocniejsza) albo może prowadzić (teza słabsza) do marginalizacji moralnej odpowiedzialności oraz utraty sprawstwa podmiotowego. Zarzut ten zakłada, że etyka kodeksowa w pełni odciąża interpretatora. W ten sposób odpowiedzialność sprowadza się do postępowania według postanowień ujętych w kodeksie etycznym. Podejmowane działanie ma charakter instytucjonalny — jest wyrazem dostosowania się do rozwiązań normatywnych, które odciążają jednostkę od podejmowania decyzji.

Przedstawiona wizja praktyki instytucjonalnej odsłania moralny świat wykonawców roli, zaprezentowany w eseju Kolonia karna ${ }^{7}$. Franz Kafka ukazuje w nim funkcjonowanie aparatu wymierzającego kary za wszystkie przewinienia, jakie popełnili żołnierze, wcześniej ukarani za określone czyny, skazani na pobyt w kolonii. Niezwykłość aparatu polega na zadawaniu każdemu skazańcowi w kolonii karnej śmierci, która trwa dokładnie dwanaście godzin. Bohaterowie opowiadania definiowani są według funkcji, jaką pełnią w kolonii: komendant, oficer, skazany żołnierz, obserwator procedury zabijania, co ma ilustrować technologiczność prezentowanego projektu. Charakterystyczna jest wypowiedź obserwatora, który dopiero co wprowadzony w przedstawiony świat praktyki ma względem niej wątpliwości, ale nie zabiera głosu, bo jak twierdzi: „Gdybym wyraził swoje zdanie, byłoby to zdanie człowieka prywatnego [...] i dlatego przyjmuję obowiązujące w zastanej praktyce imperatywy postępowania, stając się ich mimowolnie »nosicielem《"s.

Zarysowany obraz praktyki instytucjonalnej powoduje marginalizowanie sprawczego charakteru działania oraz moralnej odpowiedzialności za podejmowane czyny. Odpowiedzialność moralna zostaje zastąpiona wymiarem służebnym, w którym bycie odpowiedzialnym sprowadza się do działania zgodnie z przyjętymi regułami, na przykład określonymi w kodeksie etycznym. Odpowiedzialność służebna różni się od odpowiedzialności moralnej tym, że: „działanie jest środkiem do osiągnięcia jakiegoś zewnętrznego celu. Gdy uda się usunąć z pola widzenia zewnętrzny kontekst działania, czynność wykonywana przez urzędnika staje się celem sama w sobie"9. W ten sposób odpowiedzialność zostaje pozbawiona wymiaru moralnego. W jej miejsce wstępuje wymiar służebny, a etyczność działania mierzy się dostosowaniem do zastanych reguł ${ }^{10}$. To potencjalne niebezpieczeństwo zdają się mieć na myśli Teresa Romer i Magdalena Najda, pisząc,

${ }^{7}$ F. Kafka, Kolonia karna, [w:] idem, Wyrok, przeł. J. Kydryński, Warszawa 1957, s. 140.

${ }^{8}$ W. Kaczocha, Studia z filozofii XX wieku, Poznań 2008, s. 176.

${ }^{9}$ Z. Bauman, Nowoczesność i zagłada, przeł. T. Kuntz, Kraków 2009, s. 218.

10 T. Pietrzykowski, Czy prawnicy mają szczególne powinności moralne?, [w:] Etyka prawnicza. Stanowiska i perspektywy, red. H. Izdebski, P. Skuczyński, Warszawa 2008, s. 78 n. 
że „zaufanie do kodeksów ma źródło w lęku przed podjęciem pełnej osobistej odpowiedzialności za własne czyny"11.

Przedstawiona krytyka etyki kodeksowej sugeruje, że idea kodyfikacji zamiast przyczyniać się do poczucia odpowiedzialności za podejmowane decyzje oraz obraz praktyki, tworzy mechanizm zorganizowanej nieodpowiedzialności ${ }^{12}$. $\mathrm{Z}$ taką sytuacją możemy mieć do czynienia, gdy dyskurs zawodowy przyjmuje słownik pojęć sprowadzający się do posłuszeństwa, lojalności, bezpieczeństwa moralnego. Powoduje to osłabienie poczucia odpowiedzialności za podejmowane decyzje, ponieważ rozmywa się ona w złożonych, bezosobowych strukturach.

W innym miejscu starałem się wykazać, że zarysowaną krytykę można ukazać jako tę, która podaje w wątpliwość nie ideę etyki kodeksowej, lecz określoną jej wizję, sprowadzającą się do etyki posłuszeństwa ${ }^{13}$. Teraz jednak chciałbym podjąć się obrony etyki kodeksowej, nie tyle przedstawiając odmienny sposób myślenia o niej, ile biorąc pod rozwagę argument z pojęcia roli prawnika.

\section{TEZA O ZRÓŻNICOWANIU RÓL}

Teza o różnicowaniu ról zakłada, że wymagania związane z rolą prawnika zmuszają jej wykonawcę do dokonywania wyborów moralnych w trakcie czynności zawodowych ${ }^{14}$. Ich źródłem są konflikty między wymaganiami wiążącymi się z rolą prawnika a innymi związanymi z pełnionymi funkcjami w przestrzeni publicznej. $Z$ tezy o zróżnicowaniu ról wyprowadza się twierdzenie, że trudno być jednocześnie dobrym prawnikiem i dobrym człowiekiem, ponieważ wymagania moralne mogą być odmienne ${ }^{15}$. Twierdzenie to bywa wykorzystywane jako argument na rzecz roszczenia do integralności moralnej, budowanej na wzór prawnika-guru ${ }^{16}$. Przypomnijmy, że w wizji tej kluczowe, dla działania prawnika jako wykonawcy roli, stają się dyspozycje moralne. To, jakim człowiekiem jest jurysta, ma decydujący wpływ na wykonywane przez niego czynności zawodowe. Prezentowana wizja niesie z sobą niebezpieczeństwo w postaci realizowania wartości, które prawnik uzna za podstawowe. Takie oblicze podmiotowej sprawczości jest potencjalnym kosztem wykonywania roli poza instytucjonalnymi ramami, oferowanymi między innymi przez kodeks etyczny.

11 T. Romer, M. Najda, Etyka dla sędziów. Rozważania, Warszawa 2007, s. 151-152.

12 Zob. S. Lindroos-Hovinheimo, Justice and the Ethics of Legal Interpretation, London 2012, s. 140 .

13 P. Kaczmarek, op. cit., s. 19 n.

14 S. Stier, Legal ethics: The integrity thesis, „Ohio State Law Journal” 52, 1991, nr 2, s. 554;

W.B. Wendel, Ethics and Law. An Introduction, Cambridge 2014, s. 3-11.

15 S. Stier, op. cit., s. 560.

16 T.L. Shaffer, R.F. Cochran, Lawyers, Clients and Moral Responsibility, St. Paul, Mn 1994, s. 30-39. Zob. także R. Sarkowicz, Amerykańska etyka prawnicza, Kraków 2004, s. 64-66. 
Zdaniem Daniela Markovitsa sytuacja konfliktu między moralnością roli a moralnością społeczną $\mathrm{i}$ indywidualną jest jedną z cech zawodu prawnika (adwokata i radcy prawnego) ${ }^{17}$. Autor, przedstawiając tę właściwość, stawia pytanie, czy pełnomocnik procesowy powinien służyć interesom klientów tak gorliwie, jak tylko pozwala na to prawo, czy też powinien zachęcać klientów do przestrzegania wewnętrznych celów prawa i narzucać im rozwiązania, które ocenia za właściwe w danej sprawie ${ }^{18}$. Odpowiadając na nie, autor podkreśla, że prawnicy powinni służyć przede wszystkim swoim klientom, oddanie im głosu na sali sądowej jest zadaniem wykonywanej profesji. Uzasadniając to stanowisko, D. Markovits zwraca uwagę na cel społeczny, jakim jest zapewnienie każdemu człowiekowi prawa do obrony ${ }^{19}$.

Oprócz wspomnianej sytuacji konfliktu między moralnością instytucjonalną a moralnością indywidualną można wskazać na inne jeszcze aspekty konfliktu. Po pierwsze, możliwe są napięcia między zadaniami w ramach roli. Jak odnotowuje Ija Lazari-Pawłowska, tego rodzaju konflikty występują w profesjach, w których mamy do czynienia $\mathrm{z}$ wielością partnerów ról ${ }^{20}$. Diagnozę tę dokumentują również ustalenia Janiny Czapskiej, która przedstawia różne oblicza konfliktowości w zawodzie prawnika ${ }^{21}$. Źródłem jednego z nich jest sprzeczność oczekiwań formułowanych przez różnych nadawców, na przykład prawodawcę ustawowego a korporacyjnego. Po drugie, o konflikcie możemy też mówić, gdy osoba odgrywa kilka ról wymagających podejmowania sprzecznych działań. Im bardziej wyraźne jest zróżnicowanie pomiędzy praktykami społecznymi i ich systemami norm, tym trudniej jednostce zintegrować z sobą różne odgrywane przez siebie role. Dodajmy do tego, że wykonywanie profesji często łączy się z niepokojem, napięciem związanym z oczekiwaniami poszczególnych partnerów w roli. Stopień tego napięcia, a także reakcja na nie zależą nie tylko od charakteru osoby, lecz także na przykład od zajmowanej przez nią pozycji w strukturze instytucjonalnej22.

Zdaniem J. Czapskiej zawód prawnika możemy przedstawiać jako rolę konfliktową ${ }^{23}$. Wobec tego rodzaju roli I. Lazari-Pawłowska formułuje następującą myśl: „Ograniczenie dowolności w rozwiązywaniu konfliktów i pewien rygoryzm

17 D. Markovits, Legal ethics from the lawyer's point of view, „Yale Journal of Law \& the Humanities" 15, 2003, nr 2, s. 265; idem, A Modern Legal Ethics: Adversary Advocacy in a Democratic Age, Princeton, NJ 2008, s. 156 n.

${ }^{18}$ D. Markovits, Legal Ethics..., s. 265.

19 D. Markovits, A Modern Legal Ethics..., s. 202.

${ }^{20}$ I. Lazari-Pawłowska, Etyki zawodowe jako role społeczne, [w:] Etyka zawodowa..., s. 49 n.

${ }^{21}$ J. Czapska, Konflikty zwiazane z petnieniem roli prawnika-uczestnika wymiaru sprawiedliwości, [w:] G. Skąpska, J. Czapska, M. Kozłowska, Społeczne role prawników (sędziów, prokuratorów, adwokatów), Wrocław 1989, s. 53.

${ }^{22}$ Zwraca na to uwagę R.H. Miles, Role-set configuration as a predictor of role conflict and ambiguity in complex organizations, „Sociometry. American Sociological Association” 1977, nr 1, s. 32-33.

23 J. Czapska, op. cit., s. 46. 
wydają mi się w praktyce niektórych zawodów niezbędne. Tylko takie ograniczenie daje szanse na przewidywalność zachowań" 24 . Podstaw tego rodzaju ograniczeń autorka upatruje w specyfice wykonywanej roli. W przypadku zawodów usługowych konieczne jest zaufanie na linii profesjonalista-klient, które nie powinno zostać nadużyte. Poczucie pewności i gwarancja działania lojalnego wobec klienta jest dla I. Lazari-Pawłowskiej argumentem na rzecz kodyfikacji etyk zawodowych. Wzmacnia to stanowisko również odciążająca funkcja etyki kodeksowej. Odciążenie to może przyjąć postać szufladkowania ról i zadań, o którym pisze Ralph Turner ${ }^{25}$. Przede wszystkim szufladkowanie to ma na celu łagodzenie obciążenia związanego z koniecznością rozstrzygania ponad miarę sytuacji konfliktu, na przykład między moralnością instytucjonalną a moralnością indywidualną. Jednocześnie ma ono pozwolić na wykonywanie różnych ról w sferze życia codziennego. Można być skąpym biznesmenem, a jednocześnie hojną osobą w gronie przyjaciół. Podobnie od współpracowników w działalności zawodowej można oczekiwać staranności i skrupulatności, a w życiu rodzinnym być nad wyraz pobłażliwym wobec odmiennych zachowań i postaw. W rekomendowanej wizji uczestnictwo w wielu złożonych interakcjach zmusza do refleksji nad szufladkowaniem zadań, podejmowanymi czynnościami ${ }^{26}$.

\section{FUNKCJA ROLI PRAWNIKA}

Iwona Bogucka uzasadnienia tworzenia kodeksów etycznych upatruje w zobowiązaniu społecznym, jakie wiąże się z wykonywaniem zawodu prawnika ${ }^{27}$. Zdaniem autorki im wyższe społeczne oczekiwanie wobec profesji, tym większa potrzeba kodyfikacji zasad postępowania. Źródłem tej potrzeby jest między innymi ochrona klienta przed sprawstwem podmiotowym, w wyniku którego mielibyśmy do czynienia z działaniem prawnika poza rolą — jej strukturą instytucjonalną. Iwona Bogucka, zwracając na to uwagę, odnotowuje: „Autonomia moralna, zasadniczo cenna w kwestiach wyborów moralnych, powinna zostać ograniczona przy wykonywaniu zawodu, ze względu na interes osób poddanych kompetencji profesjonalisty" 28 .

W etyce prawniczej problem ten odnotowuje również Ted Schneyer. Autor ten wskazuje na pułapki i niebezpieczeństwa związane z przypisywaniem jurystom ponad miarę obowiązków moralnych czy też wymogów publicznych, które

${ }^{24}$ I. Lazari-Pawłowska, Etyka zawodowa bez kodeksu, „Etyka” 1994, nr 27, s. 178.

${ }^{25}$ R. Turner, Role theory, [w:] Handbook of Sociological Theory, red. J.H. Turner, New York 2006, s. 250.

${ }^{26}$ Ibidem.

${ }^{27}$ I. Bogucka, Kodeksy etyki zawodowej, [w:] Leksykon etyki prawniczej. 100 podstawowych pojęć, red. P. Skuczyński, S. Sykuna, Warszawa 2013, s. 197.

${ }^{28}$ Ibidem, s. 197-198. 
prowadzą do marginalizacji racji klienta ${ }^{29}$. Dlatego zdaniem autora podstawowym celem etyki kodeksowej powinna być ochrona klienta. Takie stanowisko bliskie jest także Katherine R. Kruse ${ }^{30}$. Według autorki odpowiedzią na zobowiązanie, jakie tworzy zaufanie do roli prawnika, powinno być kształtowanie reprezentacji prawnej na podstawie lepszego zrozumienia celów klienta ${ }^{31}$. Jak jednak zauważa K. Kruse, w debacie nad rolą prawnika bardzo często obowiązki pełnomocnika procesowego definiuje się $\mathrm{z}$ punktu widzenia dóbr publicznych ${ }^{32}$. W podejściu tym badaczka dostrzega potencjalne niebezpieczeństwa ${ }^{33}$. Zagrożeniem może być: wykorzystywanie wiedzy prawniczej do dominacji i manipulowania klientem w celu realizacji własnych celów oraz kierowanie się ideami społecznymi z pominięciem racji osoby, która powierza adwokatowi prowadzenie sprawy.

Zmiana, jaką proponuje K. Kruse, zakłada zwrócenie uwagi na racje i potrzeby klienta $\mathrm{w}$ granicach prawa. W propozycji tej wybór strategii obrończej powinien być dokonywany w trosce o interes klienta, zarówno w aspekcie moralnym, jak i finansowym. Należy także pamiętać, że działanie prawników jest ograniczone przez rozpoznawalne czynniki określone w drodze procesu demokratycznego, a więc mające silną legitymację społeczną ${ }^{34}$. Według badaczki podstawowym obowiązkiem pełnomocnika procesowego jest umożliwienie klientowi podejmowania właściwych i świadomych decyzji w zakresie prawa ${ }^{35}$.

Rekomendowana przez K. Kruse propozycja oparta jest na pojęciu autonomii klienta, rozumianej jako bycie podmiotem w sprawie, której jest się stroną. Autonomia ta budowana jest na wolności pozytywnej, umożliwiającej podejmowanie decyzji i kierowanie się racjami ważnymi dla jednostki, które mieszczą się w granicach prawa oraz moralności publicznej ${ }^{36}$. Takie ujęcie, jak podkreśla autorka, ma prowadzić do sytuacji, w której prawnik pomaga klientowi ,jak najlepiej wykorzystać formalność i nieodwracalność struktur prawnych w celu rozwiązania

${ }^{29}$ T. Schneyer, The promise and problematics of legal ethics from the lawyer's point of view, „Yale Journal of Law \& the Humanities” 16, 2004, s. 46 n.

30 Przedstawiając w dalszych rozważaniach stanowisko Katherine R. Kruse, odwołuję się do ustaleń zaprezentowanych w pracy Dystans do roli w zawodzie prawnika, Warszawa 2019, s. 29-32.

${ }^{31}$ K. Kruse, The jurisprudential turn in legal ethics, „Arizona Law Review” 2011, nr 2, s. 524 525 .

32 Ibidem, s. 506.

33 Ibidem.

34 Podobnie Richard A. Wasserstrom, który zauważa: „Gdyby adwokaci mieli zastępować poglądy ustawodawcy własnymi poglądami na to, co powinno być prawnie dozwolone, a co niedozwolone, oznaczałoby to przejście od demokracji do oligarchii adwokatów" — idem, Adwokaci jako profesjonaliści: kilka zagadnień moralnych, przeł. J. Malczewski, [w:] Moralność i profesjonalizm. Spór o pozycję etyk zawodowych, red. W. Galewicz, Kraków 2010, s. 277.

35 K. Kruse, op. cit., s. 496-497.

${ }^{36}$ Ibidem, s. 526-527. 
sporu w sposób, który zapewnia klientowi długofalowe korzyści, zachowując jego ważne relacje z ludźmi, szanuje jego wartość" 37 .

Przedstawione zadanie ochrony klienta powinny spełniać kodeksy zawodo$w^{38}$. Ochrona ta ma dwa podstawowe wymiary. $Z$ jednej strony jej celem jest zapobieganie sytuacjom, w których prawnik w działalności zawodowej kieruje się przede wszystkim moralnością indywidualną, przekonaniami politycznymi czy obyczajowymi. Z drugiej zaś strony proponowany przez K. Kruse profesjonalizm ma chronić klienta przed moralnością publiczną, presją opinii publicznej.

W proponowanym ujęciu kodeksy etyczne są ważne z punktu widzenia klienta, ponieważ nie tylko mają być formalną kotwicą, zapewniającą prawo do obrony, lecz także chronić przed swobodą interpretacyjną, indywidualnym osądem prawnika. Wskazany interes klienta można rozpatrywać jako argument społeczny, ponieważ każdy z nas może potrzebować pomocy adwokata czy radcy prawnego. Przychodzimy do prawnika w celu dowiedzenia się, czego prawo wymaga, zakazuje i dozwala, a nie moralnego osądu naszego postępowania. Stanowisko o obronie klienta w granicach prawa stanowi również obietnicę daną społeczeństwu w postaci prawa do obrony oraz wykonywania zawodu zaufania publicznego.

\section{WNIOSKI}

Sytuacja konfliktu jest cechą profesji prawniczej. Dążenie do wyeliminowania tej właściwości za cenę bezpieczeństwa moralnego niesie niebezpieczeństwo, które krytycy etyki kodeksowej definiują jako zorganizowaną nieodpowiedzialność. Zdarza się, że odpowiedzią na ten zarzut jest kształtowanie roli prawnika na dyspozycjach moralnych. W ujęciu tym bardzo ważny, dla działalności zawodowej, staje się charakter człowieka. Takie rozwiązanie, jak starałem się wykazać, może również okazać się kosztowne z punktu widzenia racji klienta oraz społeczeństwa. Odpowiedzią na oba wymienione koszty jest pojmowanie kodeksu etycznego jako zbioru reguł, w ramach których prawnik powinien się poruszać, oraz celów, do których ma dążyć.

Z przywołanej we wstępie wypowiedzi Andrew Becketta o urzeczywistnianiu od czasu do czasu sprawiedliwości i związanej z tym satysfakcji można odczytać dwie wskazówki, które korespondują z przedstawionym ujęciem kodeksu etycznego. Pierwsza z nich zakłada, że system prawny realizuje instytucjonalnie zdefiniowaną sprawiedliwość, dlatego - co do zasady — warto przyznać pierwszeństwo standardom zawodowym w rozstrzyganiu sytuacji konfliktu. Tak rozu-

${ }^{37}$ K. Kruse, Client-centred answers to legal ethics questions, [w:] Philosophical Legal Ethics. Ethics, Morals and Jurisprudence, „Legal Ethics” 13, 2010, nr 2, s. 188.

${ }^{38}$ D. Luban, Professional ethics: A new code for lawyers?, „The Hastings Center Report” 10, 1980, nr 3, s. 11. 
miana sprawiedliwość nie powinna jednak usypiać indywidualnego osądu nad dokonywanymi czynnościami. Może się bowiem okazać, że od czasu do czasu konieczna będzie rewizja racji instytucjonalnej. Zdolność do rewizji uważam za drugą wskazówkę, jaką można wyprowadzić z przywołanej rozmowy prawników.

Obie wymienione wskazówki można próbować odnieść do postanowienia o ustawicznym kształceniu i podnoszeniu kwalifikacji zawodowych, zapisanego w Zbiorze Zasad Etyki Adwokackiej i Godności Zawodu (KEA) oraz w Kodeksie Etyki Radcy Prawnego ${ }^{39}$. Znajomość standardów zawodowych i nabycie kompetencji komunikacyjnej w świecie prawa odczytuję w świetle pierwszej wskazówki. Jeśli jednak obowiązek ten potraktować szerzej, jako obejmujący coś, co Martha Nussbaum nazywa obywatelską wyobraźnią i troską o człowieczeństwo, to ważna w tym kształceniu staje się również umiejętność rewizji racji instytucjonalnych ze względu na powody społeczne, a także jednostkowe ${ }^{40}$. Proponowane ujęcie obowiązku kształcenia może być odpowiedzią na twierdzenie W. Bradleya Wendela, że „w miarę sprawiedliwe” systemy prawne muszą ostatecznie tolerować „miejscową niesprawiedliwość"41.

\title{
THE ROLE OF A LAWYER AS AN ARGUMENT IN DEFENCE OF CODEX ETHICS
}

\author{
Summary
}

The purpose of the article is to present arguments for understanding the code of ethics as a framework of: rules within which a lawyer should move, and goals to be pursued. I intend to carry out this task in three stages. Firstly, I shall present the main accusations that are put against codex ethics. This argument claims that the codical nature of professional ethics leads or may lead to a marginalisation of moral responsibility and loss of subjective agency. Then I will proceed to defend codex ethics. To this end, I refer to the concept of role, showing that the conflict situation in the legal profession is a feature of this profession. Therefore, it is necessary to build an institutional framework that allows coordinated activity in the face of various tensions. This argument reinforces the presence of the code of ethics as a safeguard against the lawyer, leaving the role in a conflict related to professional activities. The purpose of this protection is to protect the client.

Keywords: lawyer, professional role, codex ethics, moral responsibility

39 § 8 KEA — Obwieszczenie Prezydium Naczelnej Rady Adwokackiej z 27 lutego 2018 roku w sprawie ogłoszenia jednolitego tekstu Zbioru Zasad Etyki Adwokackiej i Godności Zawodu, K.Adw. z 2018 r. poz. 3; art. 14 KERP — Uchwała Nr 3/2014 Nadzwyczajnego Krajowego Zjazdu Radców Prawnych z 22 listopada 2014 roku w sprawie Kodeksu Etyki Radcy Prawnego, K.Rad.Prawn. z 2014 r. poz. 10.

${ }^{40}$ M. Nussbaum, $W$ trosce o człowieczeństwo. Klasyczna obrona reformy kształcenia ogólnego, przeł. A. Męczkowska, Wrocław 2008, rozdz. III.

${ }^{41}$ W.B. Wendel, Lawyers and Fidelity to Law, Princeton-Oxford 2010, s. 102-103. 


\section{BIBLIOGRAFIA}

Bauman Z., Nowoczesność i zagłada, przeł. T. Kuntz, Kraków 2009.

Bogucka I., Kodeksy etyki zawodowej, [w:] Leksykon etyki prawniczej. 100 podstawowych pojęć, red. P. Skuczyński, S. Sykuna, Warszawa 2013.

Bogucka I., Pietrzykowski T., Etyka w administracji publicznej, Warszawa 2009.

Czapska J., Konflikty zwiazane z petnieniem roli prawnika-uczestnika wymiaru sprawiedliwości, [w:] G. Skąpska, J. Czapska, M. Kozłowska, Społeczne role prawników (sędziów, prokuratorów, adwokatów), Wrocław 1989.

Kaczmarek P., Dystans do roli w zawodzie prawnika, Warszawa 2019.

Kaczmarek P., Kodeksy etyki zawodowej: w poszukiwaniu bezpieczeństwa moralnego w czasach niepewności, [w:] Etyka prawnicza. Stanowiska i perspektywy 3, red. H. Izdebski, P. Skuczyński, Warszawa 2013.

Kaczocha W., Studia z filozofii XX wieku, Poznań 2008.

Kafka F., Kolonia karna, [w:] idem, Wyrok, przeł. J. Kydryński, Warszawa 1957.

Kołakowski L., Etyka bez kodeksu, [w:] idem, Kultura i fetysze. Eseje, Warszawa 2009.

Kruse K., Client-centred answers to legal ethics questions, [w:] Philosophical Legal Ethics. Ethics, Morals and Jurisprudence, „Legal Ethics” 13, 2010, nr 2.

Kruse K., The jurisprudential turn in legal ethics, „Arizona Law Review” 53, 2011, nr 2.

Lazari-Pawłowska I., Etyka zawodowa bez kodeksu, „Etyka” 1994, nr 27.

Lazari-Pawłowska I., Etyki zawodowe jako role społeczne, [w:] Etyka zawodowa, red. A. Sarapata, Warszawa 1971.

Lindroos-Hovinheimo S., Justice and the Ethics of Legal Interpretation, London 2012.

Luban D., Professional ethics: A new code for Lawyers?, „The Hastings Center Report” 10, 1980, nr 3.

Łuków P., Moralność medycyny. O sztuce dobrego życia i o sztuce leczenia, Warszawa 2012.

Markovits D., Legal ethics from the Lawyer's point of view, „Yale Journal of Law \& the Humanities” $15,2003, \mathrm{nr} 2$.

Markovits D., A Modern Legal Ethics: Adversary Advocacy in a Democratic Age, Princeton, NJ 2008.

Michalik M., Społeczne przesłanki, swoistość i funkcje etyki zawodowej, [w:] Etyka zawodowa, red. A. Sarapata, Warszawa 1971.

Miles R.H., Role-set configuration as a predictor of role conflict and ambiguity in complex organizations, „Sociometry. American Sociological Association” 1977, nr 1.

Naumann J., Zbiór Zasad Etyki Adwokackiej i Godności Zawodu. Komentarz, Warszawa 2017.

Nussbaum M., W trosce o człowieczeństwo. Klasyczna obrona reformy ksztatcenia ogólnego, przeł. A. Męczkowska, Wrocław 2008.

Obwieszczenie Prezydium Naczelnej Rady Adwokackiej z 27 lutego 2018 roku w sprawie ogłoszenia jednolitego tekstu Zbioru Zasad Etyki Adwokackiej i Godności Zawodu (Kodeks Etyki Adwokackiej), K.Adw. z 2018 r. poz. 3.

Pieniążek M., Etyka sytuacyjna prawnika, Warszawa 2008.

Pietrzykowski T., Czy prawnicy maja szczególne powinności moralne?, [w:] Etyka prawnicza. Stanowiska i perspektywy, red. H. Izdebski, P. Skuczyński, Warszawa 2008.

Romer T., Najda M., Etyka dla sędziów. Rozważania, Warszawa 2007.

Sarkowicz R., Amerykańska etyka prawnicza, Kraków 2004.

Schneyer T., The promise and problematics of legal ethics from the Lawyer's point of view, „Yale Journal of Law \& the Humanities" 16, 2004.

Shaffer T.L., Cochran R.F., Lawyers, Clients and Moral Responsibility, St. Paul, Mn 1994.

Skuczyński P., Etyka adwokatów i radców prawnych, Warszawa 2016.

Stier S., Legal ethics: The integrity thesis, „Ohio State Law Journal” 52, 1991, nr 2. 
Taekema S., How to be a transnational jurist: Reflections on Cotterrell's sociological jurisprudence, „Ratio Juris” 32, 2019, nr 4.

Turner R., Role theory, [w:] Handbook of Sociological Theory, red. J.H. Turner, New York 2006.

Wasserstrom R.A., Adwokaci jako profesjonaliści: kilka zagadnień moralnych, przeł. J. Malczewski, [w:] Moralność i profesjonalizm. Spór o pozycję etyk zawodowych, red. W. Galewicz, Kraków 2010.

Wendel W.B., Ethics and Law. An Introduction, Cambridge 2014.

Wendel W.B., Lawyers and Fidelity to Law, Princeton-Oxford 2010.

Zirk-Sadowski M., Postulat etyki bezkodeksowej a stosunek prawa do moralności, ,Zeszyty Naukowe Uniwersytetu Łódzkiego. Nauki Humanistyczno-Społeczne”, seria I, 1979, z. 25. 